\section{The paradox of the alien plant Leucaena leucocephala subsp. glabrata (Rose) S. Zárate in Sicily: another threat for the native flora or a valuable resource?}

\author{
Emilio Badalamenti, ${ }^{1}$ Salvatore Pasta, ${ }^{2}$ \\ Giovanna Sala, ${ }^{1}$ Valentina Catania, ${ }^{3}$ \\ Paola Quatrini, ${ }^{3}$ Tommaso La Mantia ${ }^{1}$
}

${ }^{1}$ Agricultural, Food and Forest Sciences Department, University of Palermo;

${ }^{2}$ Institute of BioSciences and

BioResources (IBBR), Italian National

Research Council (CNR), Unit of

Palermo, Palermo; ${ }^{3}$ Department of

Biological, Chemical and

Pharmaceutical Sciences and

Technologies - STEBICEF - University

of Palermo, Italy

\begin{abstract}
With this contribution, an updated picture of the rapid expansion of Leucaena leucocephala subsp. glabrata in Sicily is provided. On the one hand, this is a quite worrying sign, as this woody species figures among the world's worst invasive alien species. On the other hand, the species shows interesting potential for production purposes (for wood, biomass and for feeding livestock), also considering its nitrogen fixation ability. Consequently, the two opposite options to cope with this species, i.e. cultivation and control/eradication, should accurately take into account the possible uses as well as its invasive behaviour.
\end{abstract}

\section{Introduction}

Leucaena leucocephala (Lam.) de Wit (fam. Fabaceae, subfam. Mimosoideae) is a woody species native to Mexico and probably to Central America and Caribbean countries. ${ }^{1}$ Two main subspecies have been described, mainly differing in the habit, i.e. the shrub-like 'common leucaena' Leucaena leucocephala (Lam.) de Wit subsp. leucocephala and the tree-like 'giant leucaena' Leucaena leucocephala subsp. glabrata (Rose) S. Zárate. ${ }^{2}$ Henceforth Leucaena leucocephala subsp. glabrata will be abbreviated as Leucaena. Also owing to its wide climatic plasticity, Leucaena was introduced in many tropical and sub-tropical countries with average annual rainfall between 750 and 1,800 mm (but even up to 3,000 $\mathrm{mm}$ ) and a dry season of 3-6 months. ${ }^{1}$ As most legumes, Leucaena hosts nitrogen-fixing rhizobia and it is considered as a promiscuous host, being nodulated by both fast- and slow-growing rhizobia belonging to the genera Ensifer, Rhizobium, and Mesorhizobium. ${ }^{3}$ The amount of nitrogen fixed by Leucaena is similar to or higher than that of crop legumes such as peanut and soybean, and most of the fixed $\mathrm{N}$ is returned to the soil via leaf litter. ${ }^{4}$ Moreover, Leucaena benefits from the mycorrhizal symbiosis for increased nutrient and water uptake, reduced susceptibility to diseases, and increased biomass and growth. Positive effects of arbuscular mycorrhizal fungi inoculation on its growth have been reported under different conditions. ${ }^{5,6}$ Due to its high nutritional value and protein content, ${ }^{2}$ fast-growing traits and rapid life-cycle, Leucaena is a multipurpose tree which has been successfully employed for ornamental purposes, as livestock fodder, to obtain biomass and firewood, as well as to improve soil fertility, to control erosion, and for the reforestation of marginal lands. ${ }^{7,8}$

However, Leucaena has also showed an invasive behaviour, rapidly spreading both in anthropogenic and ruderal habitats, as a typical light-demanding pioneer plant, and in semi-natural and forest habitats, especially if subject to frequent disturbance. ${ }^{9}$ Accordingly, it figures among the most dangerous alien species in the world. ${ }^{10}$ Leucaena has currently showed a marked preference for the often fragile oceanic island ecosystems, ${ }^{1}$ where it threatens native vegetation and biodiversity, due to its ability to establish dense monospecific stands which prevent the regeneration of native tree species, also altering the nitrogen cycle. ${ }^{11,12}$ Furthermore, its great drought resistance, and the ability to withstand rather low annual rainfall (250-350 $\mathrm{mm}),{ }^{13}$ has recently allowed Leucaena to survive in Mediterranean-climate areas like Spain, ${ }^{14}$ where it is considered invasive.

The high symbiotic promiscuity has allowed Leucaena to establish symbiosis with rhizobia native to different continents, including Europe, thus increasing its invasive potential. The ability to establish symbiosis with strains of Bradyrhizobium canariense sv genistearum has been recently reported in Portugal for the first time. ${ }^{15}$ Sicily has been the only Italian region affected by the naturalization of Leucaena until recently. ${ }^{16}$ Just last year Leucaena has been observed growing wild in Sardinia, too. ${ }^{17}$ Moreover, Leucaena holds many of the biological traits most commonly found in invasive plant species of Mediterranean islands, ${ }^{18}$ such as anemochory, summer and
Giovanna Sala, Department of Agricultural, Food and Forest Sciences University of Palermo, Viale delle Scienze 13 Ed.4, Ingr. H, 90128 Palermo, Italia.

E-mail: giovanna.sala@unipa.it

Key words: Invasive species, biomass, wood, fast-growing trees, Mediterranean

Contributions: EB and TLM conceived the research and established methodology, all authors collected and analyzed data, GS analyzed the wood samples and determined ash content, EB, SP, GS, VC, PQ and TLM wrote the manuscript.

Conflict of interest: The authors declare no potential conflict of interest.

Acknowledgements and Funding: Part of the findings presented in this paper issues from the field surveys carried out during the Projects LIFE11+ NAT/IT/000093 "Pelagic Birds" (Linosa), Life Desert Adapt LIFE16 CCA/IT/000011 (http://www.desertadapt.it/index.php/it/) (Lampedusa) and the implementation of the Programme BioDivMex Mistrals in collaboration with the Conseil National de la Recherche Scientifique (CNRS, Francia) - Site d'Etude en Ecologie Globale (Pantelleria). We thank Leonardo Scuderi (soc. Coop. Iberis) for sharing his personal unpublished data. The work was financed with Tommaso La Mantia's fund $\mathrm{Pj}$ autf 008567 .

Received for publication: 20 May 2020.

Revision received: 28 July 2020.

Accepted for publication: 28 July 2020.

This work is licensed under a Creative Commons Attribution-NonCommercial 4.0 International License (CC BY-NC 4.0).

${ }^{\circ}$ Copyright: the Author(s), 2020

Licensee PAGEPress srl, Italy

International Journal of Plant Biology 2020; 11:8637 doi:10.4081/pb.2020.8637

prolonged flowering, and abundant seed production. Like for other tree legumes, the invasive potential of Leucaena is exclusively linked to the characteristics of sexual reproduction. This monoecious and autogamous species can produce fertile offspring in a very short time, being able to reach sexual maturity within the first year of life. Then, as early as two to three years of age, seed production begins to be almost continuous throughout the year, ${ }^{1}$ even reaching 5,500 seeds $\mathrm{m}^{-2}$ year ${ }^{-1}{ }^{19}$ Leucaena was introduced to Europe almost two centuries ago in the gardens of France and England, ${ }^{20}$ but the first signs of naturalization in Europe date back only to the end of the last century. ${ }^{13}$ 


\section{Leucaena leucocephala in Sicily as an emblematic case for the Mediterranean region}

Leucaena is probably one of the best examples of alien species which could be properly used under some circumstances but should not be used in others due to its invasive behaviour. Similar is the history of eucalypts in Mediterranean habitats: suitable trees for providing high wood production in some context ${ }^{21}$ but increasingly invasive in riparian habitats. ${ }^{22}$ Hence, before choosing the most appropriate management option, it is necessary to take into account the current situation and the most likely future trends of the species in Sicily and in the whole Mediterranean area.

Leucaena was introduced to Sicily, through the Botanical Garden of Palermo, in 1793. ${ }^{16}$ Although it began to produce fertile seeds very soon, ${ }^{23}$ it has not escaped from cultivation until recently. The first ascertained cases of naturalization concerned both the southern (Agrigento) and northern (Campofelice di Roccella and Cefalù) coasts of the island..$^{16}$ About a decade later, we provide additional naturalization reports in more than 10 sites (Table 1), preferentially coastal areas, from 4 to about $120 \mathrm{~m}$ a.s.l., with about $70 \%$ of sites located at less than $50 \mathrm{~m}$ a.s.l. Its recent spread in circum-Sicilian islands is of great concern. Leucaena has been introduced for ornamental purposes, and more rarely in reforestation, to Pantelleria ${ }^{24}$ (already cultivated there in spring 1992, T. La Mantia, P. Quatrini and S. Pasta, pers. obs.), Ustica, Linosa and Lampedusa. ${ }^{25}$ More recently, it behaves as a casual alien species in Linosa ${ }^{26}$ and Favignana, ${ }^{27}$ and it is nearly fully established in Lampedusa (Table 1), where it has been observed growing wild since 2012 . Hence, Leucaena should be added to other exotic woody species that are rapidly spreading in Sicily, like Acacia cyclops A.Cunn. ex G.Don ${ }^{28}$ and Melia azedarach L. ${ }^{29}$ In Sicily, Leucaena is currently able to establish exclusively within disturbed and anthropogenic habitats such as roadsides and brownfields of suburban areas, irrigated woody and herbaceous crops, and public or private green areas.
Conversely, some biotic and/or abiotic barriers seem to prevent its establishment into seminatural and natural environments. In support of this, we report an emblematic field observation from a mature Leucaena individual cultivated in the boundary of a countryside in Palermo Province (municipality of Trappeto). Here, the species has shown high reproductive fitness, and a number of seedlings, saplings or young trees enjoy regular irrigation and tillage (Figure 1). Conversely, Leucaena appears unable to

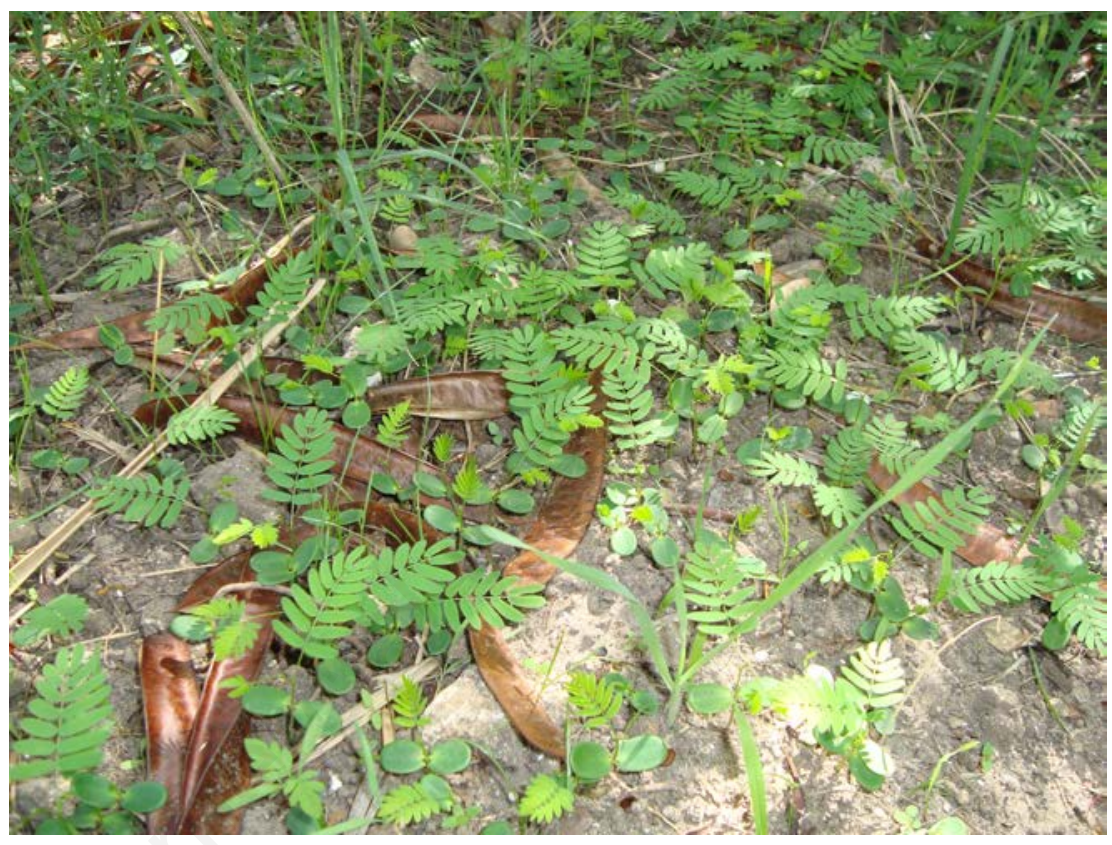

Figure 1. Massive natural regeneration of Leucaena underneath a mature individual cultivated in a coastal area (Trappeto, province of Palermo) (photo by E. Badalamenti).

Table 1. Historical and new records of naturalization events by Leucaena leucocephala subsp. glabrata in Sicily.

\begin{tabular}{|c|c|c|c|c|}
\hline Year & $\begin{array}{l}\text { Location } \\
\text { (Municipality, Province) }\end{array}$ & $\begin{array}{l}\text { Altitude } \\
\text { (m a.s.l.) }\end{array}$ & Habitat & $\begin{array}{l}\text { Reference } \\
\text { or observer/s }\end{array}$ \\
\hline 2007 & $\begin{array}{l}\text { Agrigento }(\mathrm{AG}) \\
\text { Campofelice di Roccella (PA) } \\
\text { Cefalù (PA) }\end{array}$ & $\begin{array}{l}\text { n.s. } \\
\text { n.s. } \\
\text { n.s. }\end{array}$ & $\begin{array}{l}\text { Abandoned lands, roadside along the highway SS } 118 \\
\text { Citrus orchard, near the rail station } \\
\text { Roadside }\end{array}$ & $R \& D$ \\
\hline 2007 & Ribera (AG), at the crossroads for "Piana Grande" & 90 & Roadside (together with Asclepias fruticosa L.) & LS \\
\hline 2009 & Trappeto (PA) & 65 & Irrigated fields & $\mathrm{EB}$ \\
\hline 2011-2015 & Palermo (PA) & $35-94$ & $\begin{array}{l}\text { Urban and suburban environments (gardens, irrigated pots, } \\
\text { road borders and trees, the Botanical Garden, citrus groves) }\end{array}$ & EB \\
\hline 2011 & Service area of the Highway SS 115 (Ribera, AG) & 25 & Small escarpment on abandoned land & EB \& TLM \\
\hline 2011 & Isola delle Femmine (PA) & 33 & Roadsides & $\mathrm{EB}$ \\
\hline 2012-2020 & Lampedusa (Porto Vecchio) (AG) & $4-10$ & Palm grove in harbour area and sandy soils, and small escarpment & EB \& TLM \\
\hline 2012 & Ribera (Secca Grande) (AG) & 23 & Roadside & EB \\
\hline 2013 & Villagrazia di Palermo (PA) & 118 & Irrigated fields & $\mathrm{EB}$ \\
\hline 2014 & Cefalù (PA) & 47 & Urban areas & $\mathrm{EB}$ \\
\hline 2014 & Balestrate (PA) & 5 & Afforestation and roadside & $\mathrm{EB}$ \\
\hline 2014 & Favignana (TP) & 10 & Base of a sidewalk & LM \\
\hline 2015 & Linosa $(A G)$ & 13 & Private garden & P\&al \\
\hline 2019 & Pantelleria (TP) & 15 & Abandoned lands & EB \& TLM \\
\hline
\end{tabular}

EB $=$ E. Badalamenti, TLM $=$ T. La Mantia, LM=L. Maggionii ${ }^{27}$, P\&al $=$ Pasta $e^{2} a^{28}$, R\&D $=$ Raimondo \& Domina ${ }^{16}$, LS $=$ L. Scuderi; n.s.. not specified. 
overcome the competition of the native species of the adjacent perennial grassland dominated by Hyparrhenia hirta (L.) Stapf, even if this plant community is very disturbed, as indicated by local abundance of Dittrichia viscosa (L.) Greuter, and with no doubt is easily reachable by Leucaena seeds.

Such evidence, together with the current distribution, suggests a low competitive ability against native flora. However, it is worth highlighting its early achievement of sexual maturity and its ability to rapidly spread even at medium to long distances, a key factor for invasive plants. ${ }^{30}$ Although the majority of naturalized Leucaena individuals were observed growing near the mother plants, some of them have been detected more than 500 meters far from them. Furthermore, the Sicilian nuclei promptly resprout after fire passage and/or mechanical damages caused by periodic road maintenance interventions. A remarkable plasticity in terms of light requirements was also observed, although Leucaena is a typical pioneer and light-demanding species. In the Campus of the SAAF Department of the University of Palermo, numerous seedlings and saplings were found under the canopy of large exotic fig trees such as Ficus microcarpa L. and Ficus macrophylla f. columnaris (C. Moore) D.J. Dixon (Figure 2). Both species are widely known for the high shading, one of the reasons why Ficus microcarpa is considered an excellent species for urban streets. This is further confirmed by the occurrence under their canopies of Hedera helix L., a shade-tolerant species (Figure 2). The adaptation to a wide range of soil conditions has been also pointed out. In the port of Lampedusa Island, Leucaena was found invading a date Palm (Phoenix dactylifera L.) grove just a few steps from the sea, on purely sandy and brackish soil (Figure 3). The species has been observed in similar environments in Israel. ${ }^{16}$

\section{Future perspectives: to use or not to use Leucaena?}

One constraining factor for the future spread of Leucaena in Sicily is its use, currently limited to public and private green areas. On the other hand, the growing number of reports and the characteristics of Leucaena would suggest to be cautious when assessing its invasive potential in Mediterranean-climate habitats. ${ }^{13}$ The expected climatic trends could favour the success of the species and the speed of its future invasion. ${ }^{31}$ It is therefore of great importance to carry out regular monitoring of known nuclei, especially those close to protected areas, natural and semi-natural environments and island ecosystems, which are particularly vulnerable to the proliferation of invasive alien species. In this sense, it is of great concern the recent spread of Leucaena in Pantelleria National Park, a Mediterranean island with a high biodiversity heritage. As a precautionary measure, Leucaena should be excluded from afforestation interventions in similar sites, in order to prevent fast spreading like that recently performed by Acacia spp. ${ }^{32}$

Contrariwise, several experiments have been recently carried out to verify the potential of Leucaena for productive purposes. Particularly, Rhizobium spp. strains isolated from Acacia saligna (Labill.) H.L. Wendl. and Prosopis spp. root nodules were found to promote the growth and establishment of Leucaena individuals (P. Quatrini pers. obs.). The subsequent naturalization of the species has proved its plasticity and ability to find in Mediterranean soils the necessary symbiont microorganisms. Other field experiments proved that Leucaena is able to produce a high amount of wood even under stressful climatic conditions such as limited water availability. ${ }^{7}$ A preliminary test of the productive potential of the species was carried out, and the first experimental data are below reported. In a small area with homogeneous soil conditions and uniform plant growth, seven woody disks from seven trunks of Leucaena plants, cut at the base, were sampled. The age of the sampled plants ranged from 2 to 7 years. The mean annual diameter increment was 1.20 $\mathrm{cm} \mathrm{year}^{-1}$, with the younger trees (2-4

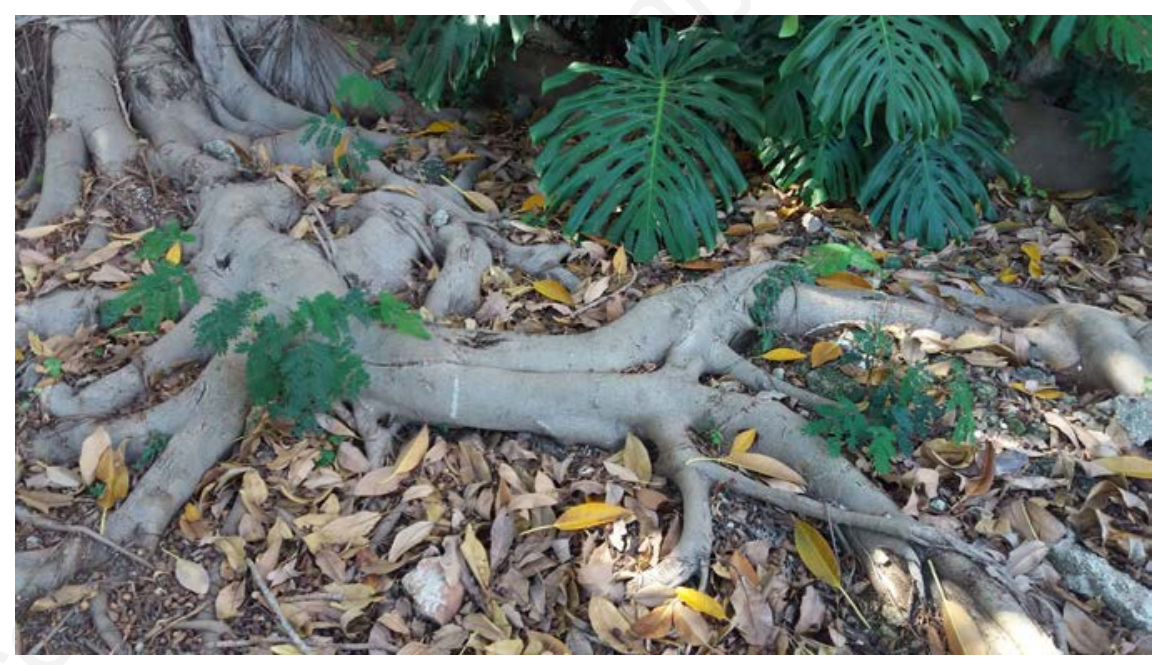

Figure 2. Leucaena saplings growing under the shady canopy of Ficus macrophylla f. columnaris at the Campus of SAAF Department (University of Palermo). Please remark the lack of other plant species except for Hedera helix (photo by E. Badalamenti).

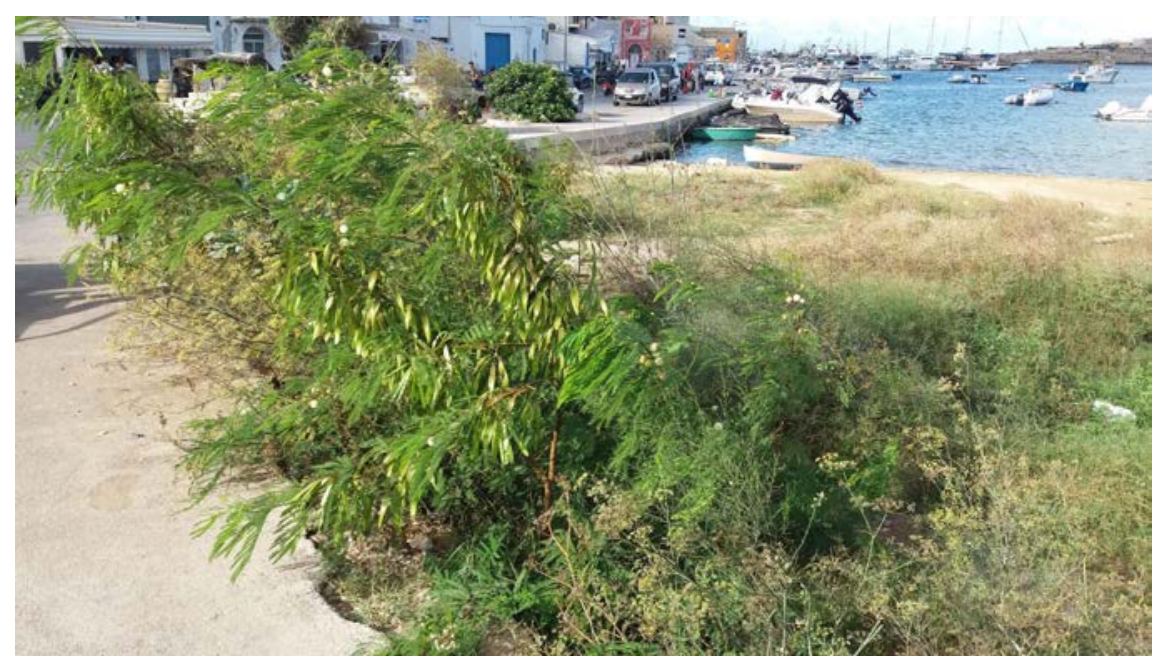

Figure 3. Naturalized young Leucaena individual growing at the Port of Lampedusa. 
years) showing the highest increment rate $\left(1.77 \mathrm{~cm} \mathrm{year}^{-1}\right)$. Regarding fuel properties of Leucaena biomass, Feria et al. $(2011)^{33}$ reported calorific values equal to $18.95 \mathrm{MJ}$ $\mathrm{kg}^{-1}$, i.e. higher than those obtained from the residues of food plants and agricultural crops. In our wood samples, the ash content varied from 1.41 to $3.73 \%$ of dry weight in plants with diameter from 2.2 to $4.3 \mathrm{~cm}$. The young plants showed the highest content. The values of ash content reported in our work are similar to those obtained in other countries. ${ }^{33}$ According to the ruling ISO 17225-1:2014, defining fuel quality classes and specifications for solid biofuels, the analyzed wood samples of Leucaena would be classified as A1.5 $(\leq 1.5 \%)$. These preliminary results suggest a good potential of Leucaena either for fodder or for wood/biomass. In both cases, it is important to let Leucaena being browsed before the pods harden, thus preventing them from dispersing their seeds through grazing and cutting. Indeed, Leucaena is worldwide a wellappreciated leguminous plant for fodder and animal nutrition due to a very high nutritional value of its leaves, even comparable to that of Medicago sativa $\mathrm{L}$. (alfalfa). ${ }^{34}$ For instance, this species was found to increase milk production and forage crude protein content compared to traditional forage in cows. ${ }^{35}$ Other promising uses of Leucaena are linked to traditional medicine, especially in south-east Asian countries $^{36}$ but also in South Africa. ${ }^{37}$ For instance, in Malaysia this species is included among the most popular plants for the antidiabetic properties of seed extracts, having a strong inhibitory effect against $\alpha$-glucosidase. Differently, in the Indonesian Archipelago seeds are used as anthelmintic, ${ }^{38}$ whereas in South Africa Leucaena is employed to alleviate pains and inflammations, and an antioxidant effect of leaves extract was also proved in in vitro experiments. ${ }^{37}$

In conclusion, Leucaena could be employed in agricultural areas or in agroforestry systems where the presence of man is constant. The species appears particularly promising to supply forage in semi-arid Mediterranean countries where fodder availability for livestock is a crucial issue, exacerbated by global warming. As Leucaena needs very low energy inputs, its cultivation could represent a sustainable alternative in these nutrient- and water-limited environments. To reduce the chance to spread in nearby areas where it could be noxious, regular monitoring activities are required in order to keep it under control. We think it is possible to distinguish areas where Leucaena cultivation is suitable and useful, and it does not harm the neighbour- ing vegetation and biodiversity, and areas where Leucaena should be cleared at all to prevent its invasion. As a precautionary measure, the introduction of Leucaena within protected areas (e.g. those belonging to Natura2000 network) should be strictly forbidden.

\section{References}

1. Binggeli P, Hall JB, Healey JR. An Overview of Invasive Woody Plants in the Tropics. School of Agricultural and Forest Science Publication No.13. University of Wales, Bangor, 1998.

2. Bageel A, Honda MDH, Carrillo JT, Borthakur D. Giant leucaena (Leucaena leucocephala subsp. glabrata): a versatile tree-legume for sustainable agroforestry. Agrofor Syst 2020;94:251-68.

3. Wang FQ, Wang ET, Zhang YF, Chen WX. Characterization of rhizobia isolated from Albizia spp. in comparison with microsymbionts of Acacia spp. and Leucaena leucocephala grown in China. Syst Appl Microbiol 2006;29:502-17.

4. Peoples MB, Herridge DF, Ladha JK. Biological nitrogen fixation: an efficient source of nitrogen for sustainable agricultural production? Plant Soil 1995;174:3-28.

5. Manjunath A, Hue NV, Habte M. Response of Leucaena leucocephala to vesicular-arbuscular mycorrhizal colonization and rock phosphate fertilization in an Oxisol. Plant Soil 1989;114:127-33.

6. Zhan F, He Y, Yue X, et al. Effect of mycorrhizal inoculation on plant growth, nutrients and heavy metals uptake by Leucaena leucocephala. Fresenius Environ Bull 2016;2:176067.

7. National Research Council, 1980. Firewood crops: shrub and tree species for energy production. Washington D.C.: National Academy of Sciences; 1980.

8. Mullen BF, Gutteridge RC. Wood biomass production of Leucaena in subtropical Australia. Agrofor Syst 2002;55:195-205.

9. Wolfe BT, Van Bloem SJ. Subtropical dry forest regeneration in grass-invaded areas of Puerto Rico: Understanding why Leucaena leucocephala dominates and native species fail. For Ecol Manage 2012;267:253-61.

10. Richardson DM, Rejmánek M. Trees and shrubs as invasive alien species - a global review. Divers Distrib 2011;17:788-809.

11. Yoshida K, Oka S. Invasion of Leucaena leucocephala and its effects on the native plant community in the Ogasawara (Bonin) Islands. Weed Technol 2004;18:1371-75.

12. Guézou A, Pozo P, Buddenhagen C. Preventing establishment: an inventory of introduced plants in Puerto Villamil, Isabela Island, Galapagos. PLoS ONE 2007;2:e1042.

13. Dana E, Randall RP, Sanz-Elorza M, Sobrino E. First evidence of the invasive behaviour of Leucaena leucocephala in Europe. Oryx 2003;37:14.

14. Sanz-Elorza M, Dana ED, Sobrino E. Atlas de las Plantas Alóctonas Invasoras en España. Madrid: Dirección General para la Biodiversidad; 2004.

15. Ramírez-Bahena MH, Flores-Félix JD, Velázquez E, Peix Á. The Mimosoid tree Leucaena leucocephala can be nodulated by the symbiovar genistearum of Bradyrhizobium canariense. Syst Appl Microbiol 2020;43:126041.

16. Raimondo FM, Domina G. Two new Mimosaceae naturalized in Italy. Fl. Medit. 2007;17:209-16.

17. Galasso G, Domina G, Andreatta S, et al. Notulae to the Italian alien vascular flora: 8. Italian Botanist 2019;8:63-93.

18. Lloret F, Medail F, Brundu G, et al. Species attributes and invasion success by alien plants on Mediterranean islands. J Ecol 2005;93:512-20.

19. Marques AR, Costa CF, Atman APF, Garcia QS. Germination characteristics and seedbank of the alien species Leucaena leucocephala (Fabaceae) in Brazilian forest: Ecological implications. Weed Res 2014;54:576-83.

20. Don G. A general history of the dichlamydeous plants. Vol. II Calyciflorae. London: Gilbert \& Rivington printers; 1832: pp.875.

21. La Mantia T. Storia dell'eucalitticoltura in Sicilia. Naturalista sicil 2013;37:587628.

22. Badalamenti E, Cusimano D, La Mantia $\mathrm{T}$, et al. The ongoing naturalisation of Eucalyptus spp. in the Mediterranean Basin: new threats to native species and habitats. Aust Forestry 2018;81:239-49.

23. Gussone G. Index seminum anni 1825 quae ab horto regio in Boccadifalco pro mutua commutatione exhibentur. Palermo, 1895.

24. Montoleone E. Leucaena leucocephala subsp. glabrata (Rose) Zárate. Acta Plantarum, Forum 2013 http://www.actaplantarum.org/floraitaliae/viewtopic.php?t=46729\&p=300473 \#p300473.

25. Domina G, Mazzola P, Flora ornamentale delle isole circumsiciliane. Quad Bot amb Appl 2008;19:107-19.

26. Pasta S, Ardenghi NMG, Badalamenti 
E, et al. The alien vascular flora of Linosa (Pelagie Islands, Strait of Sicily): update and management proposals. Willdenowia 2017;47:135-44.

27. Maggioni L. Leucaena leucocephala subsp. glabrata (Rose) Zárate. Acta Plantarum, Forum 2014 http://www.actaplantarum.org/floraitaliae/viewtopic.php?t=68353\&p=435254 \#p435254.

28. Pasta S, Badalamenti E, La Mantia T. Acacia cyclops A. Cunn. ex G. Don Leguminosae) in Italy: a first case of naturalization. Anales Jard Bot Madrid 2012; 69:193-200.

29. Badalamenti E, Cusimano D, La Mantia T, Pasta S. The recent spread of the invasive woody alien plant Melia azedarach L. (Meliaceae) in Sicily. Naturalista sicil 2013;37:505-13.

30. Richardson DM, Pysek P, Rejmánek M, et al. Naturalization and invasion of alien plants: concepts and definitions. Divers Distrib 2000;6:93-107.
31. Chiou CR, Wang HH, Chen YJ et al. Modeling Potential Range Expansion of the Invasive Shrub Leucaena leucocephala in the Hengchun Peninsula, Taiwan. Invasive Plant Sci Manage 2013;6:492-501.

32. Badalamenti E. Gristina L, La Mantia T, et al. Relationship between recruitment and mother plant vitality in the alien species Acacia cyclops A. Cunn. ex G. Don. For Ecol Manage 2014;331:23744.

33. Feria MJ, López F, García JC, et al. Valorization of Leucaena leucocephala for energy and chemicals from autohydrolysis. Biomass Bioenergy 2011;35:2224-33.

34. Zayed MZ, Zaki MA, Ahmad FB, et al. Comparison of mimosine content and nutritive values of Neolamarckia cadamba and Leucaena leucocephala with Medicago sativa as forage quality index. Int J Scientific Technology Res 2014; 3:146-50.
35. Sarabia-Salgado L, Solorio-Sánchez F, Ramírez-Avilés L, et al. Increase in milk yield from cows through improvement of forage production using the N2fixing legume Leucaena leucocephala in a silvopastoral system. Animals 2020;10:734.

36. Wan-Nadilah WA, Khozirah S, Khatib A, et al. Evaluation of the $\alpha$-glucosidase inhibitory and free radical scavenging activities of selected traditional medicine plant species used in treating diabetes. Int Food Res J 2018;26:75-85.

37. Dzoyem JP, Eloff JN. Anti-inflammatory, anticholinesterase and antioxidant activity of leaf extracts of twelve plants used traditionally to alleviate pain and inflammation in South Africa. J Ethnopharmacol 2015;160:194-201.

38. Bahtiar A, Vichitphan K, Han J. Leguminous plants in the Indonesian archipelago: Traditional uses and secondary metabolites. Nat Prod Comm 2017;12:461-72. 